\title{
EXPERIMENTAL NEONATAL DIARRHOEA CAUSED BY AN ENTEROPATHOGENIC STRAIN OF ESCHERICHIA COLI IN PIGLETS: A STUDY OF THE DISEASE AND THE EFFECT OF VACCINATING THE DAM
}

\author{
J. M. Rutter AND J. C. Anderson \\ Agricultural Research Council, Institute for Research on Animal Diseases, \\ Compton, nr Newbury, Berkshire
}

Neonatal diarrhoea associated with enteropathogenic strains of Escherichia coli is an important cause of death in piglets. The disease is characterised by the rapid proliferation of one of the porcine enteropathogenic strains of $E$. coli in the small intestine of susceptible piglets (Smith and Jones, 1963) followed by profuse diarrhoea. Substances designated enterotoxins are produced by enteropathogenic strains of E. coli (Smith and Halls, 1967; Gyles and Barnum, 1969) and enterotoxin production in vivo may be the cause of the diarrhoea. However, the enteropathogenic strain must first become established in the alimentary tract, and factors that influence this are poorly understood.

Several attempts have been made to control neonatal diarrhoea by vaccinating the dam during pregnancy. Gordon and Luke (1958) stated that the vaccination of sows with an autogenous $E$. coli vaccine reduced the diarrhoea and mortality of piglets. On the other hand, Jones, Sellers and Smith (1962) reported that vaccination of the sow had no apparent effect on the incidence of diarrhoea. The results of these field trials should be interpreted cautiously because the piglets were not exposed to a defined challenge by an enteropathogenic strain.

The aim of the present study was to investigate the development of neonatal diarrhoea in conventional piglets after oral administration of an enteropathogenic strain of E. coli. The infection procedure described by Saunders et al. (1963) was used and particular attention was paid to the establishment of the enteropathogenic strain in the intestine. Colostrum from the dams was examined to determine whether the presence of agglutinating antibodies or bactericidal activity was related to the variations in susceptibility of piglets from different litters. In an attempt to clarify the effect of vaccination on the development of the disease, piglets from vaccinated dams were challenged with the enteropathogenic strain.

\section{MATERIALS AND METHODS}

Animals. Twelve pregnant gilts were obtained from a closed herd of Large White pigs maintained on the Institute farm. The gilts were transported to loose-boxes within the Institute isolation compound at least $1 \mathrm{wk}$ before the expected dates of farrowing and were housed in individual farrowing crates. Each loose-box was divided into two pens by means of straw bales; a creep and an infra-red lamp was provided for each litter.

Received 29 July 1971; accepted 5 Oct. 1971.

J. MED. MICROBIOL.—VOL. 5 (1972) 
Bacterial strains. Strains of Escherichia coli with antigenic formulae O149:K91(B), $\mathrm{K} 88 \mathrm{ac}(\mathrm{L})$; O147: K89(B),K88ac(L); O141:K85ab(B),K88ab(L); and O141 : K85ab-K85ac(B) were obtained as cultures on Dorset's egg medium. Once the purity and identity of each culture had been confirmed, the strains were stored as freeze-dried cultures, or on Dorset's egg medium at $4^{\circ} \mathrm{C}$. A mutant strain, J2, used in bacterial agglutination tests, lacked the K88 surface antigen; this strain was obtained by ethidium bromide treatment of an O149:K91(B), $\mathrm{K} 88 \mathrm{ac}(\mathrm{L})$ strain (Mr G. W. Jones, personal communication). The strain that was used in the infection studies belonged to the O149:K91(B),K88ac(L) group (Ørskov et al., 1969). The pathogenicity of this organism was established by its ability to produce typical, fatal, neonatal diarrhoea in a piglet; the strain was re-isolated from the anterior duodenum, purified and lyophilised. The challenge bacterial suspension was prepared in two batches and each batch was used to infect piglets from non-vaccinated and vaccinated dams. The organism was subcultured on glucose nutrient agar plates (Sojka, 1965, p. 218), harvested with sterile saline, washed three times and resuspended in saline, then stored at $-70^{\circ} \mathrm{C}$.

Infection procedure. The bacterial suspension was thawed and diluted in saline to provide approximately $10^{7}$ viable organisms per $\mathrm{ml}$. The small variations in the viable counts of the challenge suspension were due to a gradual reduction in viability of the organism during storage at $-70^{\circ} \mathrm{C}$ and to errors in the estimation of the dilution necessary to provide $10^{7}$ organisms per $\mathrm{ml}$. The number of organisms in each challenge suspension was accurately determined by viable counts (see below). Each piglet was collected at birth and the bacterial suspension was administered by means of a 2-ml disposable syringe to which a length of thinbore polythene tubing was attached. The tubing was passed into the stomach of the piglet and $1 \mathrm{ml}$ of bacterial suspension was given.

Rectal swabs. Rectal swabs were taken at 9.30 a.m. each day for 6 days after infection. The piglets were considered to be "excreting" the organism if the aerobic bacterial flora cultured from rectal swabs contained more than 30 per cent. of the enteropathogenic strain.

Necropsy procedure. The abdomen was opened and samples were taken from the stomach contents, the anterior duodenum, and subsequently at 24 -in. $(c .60-\mathrm{cm})$ intervals along the small intestine, by making a small incision in the wall of the gut and inserting a sterile swab. The aerobic bacterial flora cultured from the small intestine of piglets that died with clinical signs of experimental neonatal diarrhoea (E.N.D.) contained at least 30 per cent. of the enteropathogenic strain. Therefore, death was attributed to E.N.D. if a sample cultured from at least one level of the small intestine contained more than 30 per cent. of the enteropathogenic strain.

Culture media. Swabs were cultured on blood agar plates containing Hartley's broth (Cruickshank, 1968) as the basal medium to which bovine blood (5 per cent. v/v) was added. All culture plates were incubated aerobically at $37^{\circ} \mathrm{C}$.

Enumeration of the enteropathogenic strain in swabs. The proportion of the enteropathogenic strain cultured from rectal and intestinal swabs was determined by counting the number of colonies produced by the enteropathogenic strain in a total of 100 colonies. The enteropathogenic strain was provisionally identified by the zones of haemolysis that surrounded colonies on blood agar. The identity of the strain was confirmed by slide agglutination tests with a 1 in 10 dilution of an antiserum prepared in a rabbit against live $\mathbf{J} 2$ organisms.

Viable counts. Ten-fold dilutions of the bacterial suspensions were prepared in quarterstrength Ringer solution (Oxoid Ltd) and $6 \times 0.02 \mathrm{ml}$ volumes of each dilution were dropped on to blood agar plates. The viable count was estimated from dilutions that on average yielded approximately $\mathbf{5 0}$ colonies per drop.

Vaccination procedures. Vaccine was obtained as an experimental batch from a commercial source. It contained two isolates of the O149:K91(B), K88ac(L) group grown on glucose nutrient agar, killed with 0.28 per cent. ( $\mathrm{v} / \mathrm{v}$ ) formaldehyde and then suspended in saline to give a final concentration of $8 \times 10^{8}$ organisms per ml. No adjuvant was incorporated. Each gilt received $5 \mathrm{ml}$ of the vaccine subcutaneously in the flank 4 and 2 wk before the expected date of farrowing. Non-vaccinated gilts received subcutaneous injections of $5 \mathrm{ml}$ of saline. 
Samples of serum and colostrum. The gilts were sedated with "Suicalm" (Azaperone, Janssen Pharmaceutical) and blood was removed from a marginal ear vein. Samples were taken 4, 2 and $1 \mathrm{wk}$ before farrowing; the blood was held at room temperature overnight and the serum was then separated by centrifugation. Samples of colostrum were obtained from each mammary gland at farrowing and pooled. The colostrum was incubated at $37^{\circ} \mathrm{C}$ with rennet ( 2 per cent. $\mathrm{v} / \mathrm{v}$ ) until a curd formed, then the whey was separated by centrifugation. Samples were stored at $-27^{\circ} \mathrm{C}$ until required.

Bacterial agglutination tests. Bacterial agglutination tests were performed with Microtiter apparatus (Cooke Engineering Co.) and $0.025-\mathrm{ml}$ volumes of material. The antigen was prepared by harvesting growth from glucose nutrient agar plates in 0.25 per cent. phenol in saline and then diluting the suspension until its opacity was equivalent to that of tube 4 (Opacity tubes, Burroughs Wellcome and Co.). Two-fold dilutions of serum were made in saline and $0.025 \mathrm{ml}$ of the antigen was added. The plates were incubated for $2 \mathrm{hr}$ at $37^{\circ} \mathrm{C}$, and then at $4^{\circ} \mathrm{C}$ overnight.

Passive haemagglutination tests. The passive haemagglutination test described by Sojka $(1965$, p. 211) was used. The tests were performed in $0.025-\mathrm{ml}$ volumes with the Microtiter apparatus. The antigen was heated at $100^{\circ} \mathrm{C}$ for $2 \mathrm{hr}$ and 3 per cent. sensitised sheep red cells were used.

Bactericidal tests. The bactericidal activity of colostrum was determined with and without complement and lysozyme (Adinolfi et al., 1966). Complement (fresh guinea-pig serum) was absorbed for $16 \mathrm{hr}$ at $4^{\circ} \mathrm{C}$ with a packed cell suspension of the enteropathogenic strain. Eggwhite lysozyme (Sigma Chemical Company) was used as a stock solution (10 $\mathrm{mg}$ per $\mathrm{ml})$. The colostrum samples were diluted 1 in 2 with saline. The bacterial suspension (see Infection procedure) was diluted to contain approximately $6 \times 10^{6}$ organisms per $\mathrm{ml}$. The final volume of each test mixture was $0.6 \mathrm{ml}$, and consisted of colostrum $0.1 \mathrm{ml}$, complement $0.3 \mathrm{ml}$, lysozyme $0.1 \mathrm{ml}$ and bacterial suspension $0.1 \mathrm{ml}$. In tests with colostrum alone, the volume was adjusted by the addition of diluent ( 0.06 per cent. $\mathrm{MgCl}_{2}$ in saline). The tests were incubated for $1 \mathrm{hr}$ at $37^{\circ} \mathrm{C}$ in a waterbath and viable counts were performed before and after incubation.

\section{RESULTS}

\section{Infection experiments with litters from non-vaccinated dams}

\section{Mortality of piglets}

The mortality of piglets in each litter that was attributable to experimental neonatal diarrhoea (E.N.D.) is shown in table I. Different litters varied in their susceptibility to the enteropathogenic strain; the maximum mortality was five of nine infected (litter 6) and the minimum mortality was one of ten (litter 3 ). The total mortality attributed to E.N.D. was 38 per cent. ( 20 of 53 piglets) and 17 of 20 piglets died within $48 \mathrm{hr}$ of infection. The deaths of seven other piglets were not attributed to E.N.D.; in samples cultured from the small intestine of four of these piglets the enteropathogenic strain represented less than 1 per cent. of the aerobic flora, and in samples from the other three piglets the strain represented less than 30 per cent.

\section{Onset of diarrhoea and excretion of the enterpathogenic strain}

Thirty-five of 50 surviving piglets had diarrhoea within $24 \mathrm{hr}$ of oral administration of the enteropathogenic strain (see table II), but in cultures from rectal swabs of only 26 of these 35 piglets was the enteropathogenic strain more than 30 per cent. of the flora. On the basis of these results, two litters (nos. 3 and 4) did not allow the enteropathogenic strain to proliferate in the alimentary tract 


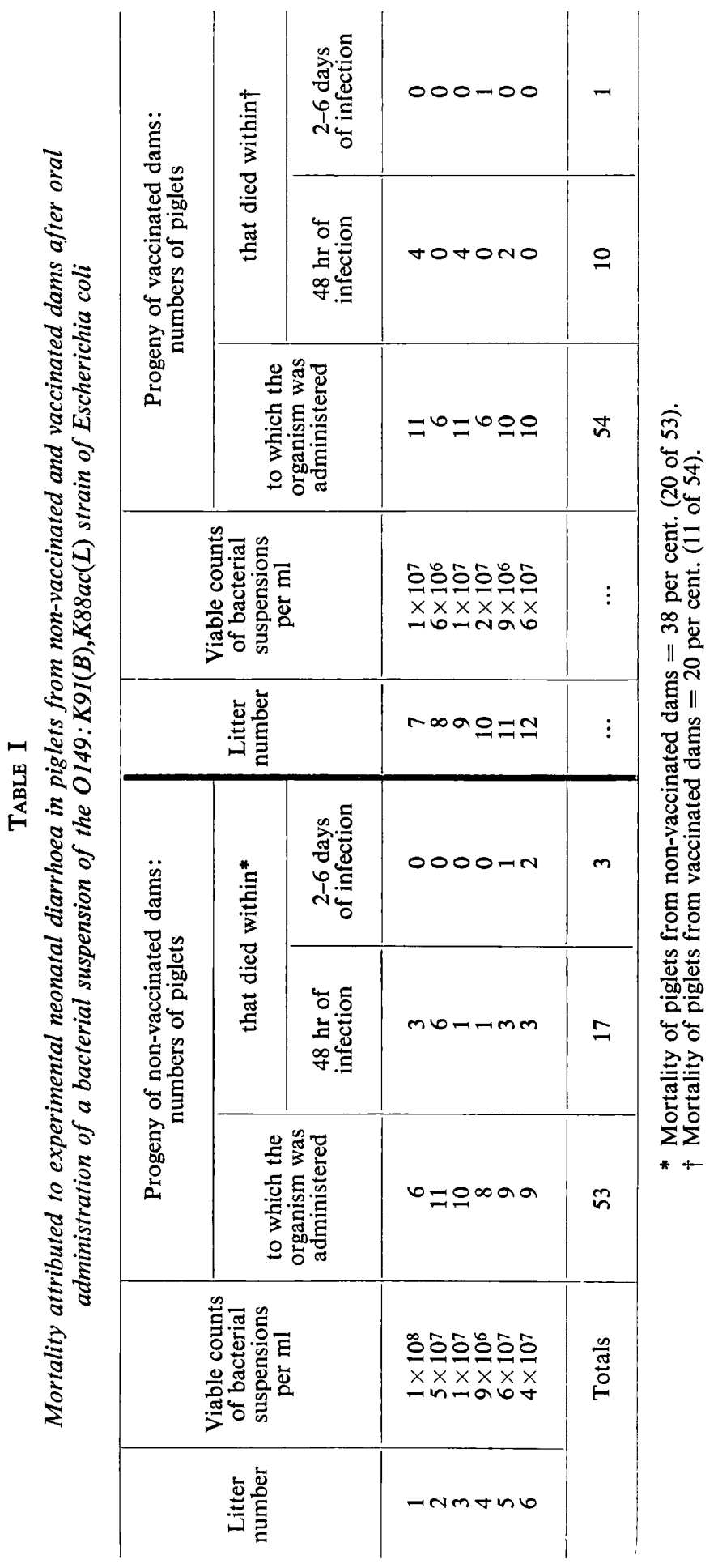


and these litters showed least mortality (see table I). Nevertheless, six of ten piglets in litter no. 3 had diarrhoea $16 \mathrm{hr}$ after infection. Although the majority of piglets in litter no. 2 were highly susceptible in terms of mortality, diarrhoea and excretion of the strain, the survivors did not excrete the enteropathogenic strain after $16 \mathrm{hr}$.

\section{Distribution of the enteropathogenic strain at necropsy}

The distribution of the enteropathogenic strain in samples taken from the small intestine at necropsy is shown in table III. The infecting strain was recovered as more than 80 per cent. of the aerobic bacterial flora from 84 of 118

\section{TABLE II}

The incidence of diarrhoea and recovery of the $0149: K 91(B), K 88 a c(L)$ strain of Escherichia coli within $24 \mathrm{hr}$ of oral administration to piglets from non-vaccinated and vaccinated dams

\begin{tabular}{|c|c|c|c|c|c|c|c|}
\hline \multirow{2}{*}{$\begin{array}{c}\text { Litter } \\
\text { number }\end{array}$} & \multicolumn{3}{|c|}{$\begin{array}{l}\text { Progeny of non-vaccinated dams: } \\
\text { numbers of piglets }\end{array}$} & \multirow{2}{*}{$\begin{array}{c}\text { Litter } \\
\text { number }\end{array}$} & \multicolumn{3}{|c|}{$\begin{array}{l}\text { Progeny of vaccinated dams: } \\
\text { numbers of piglets }\end{array}$} \\
\hline & surviving* & $\begin{array}{c}\text { with } \\
\text { diarrhoea }\end{array}$ & $\begin{array}{l}\text { excreting } \\
\text { the strain } \dagger\end{array}$ & & surviving* & $\begin{array}{c}\text { with } \\
\text { diarrhoea }\end{array}$ & $\begin{array}{l}\text { excreting } \\
\text { the strain } \dagger\end{array}$ \\
\hline $\begin{array}{l}1 \\
2 \\
3 \\
4 \\
5 \\
6\end{array}$ & $\begin{array}{c}6 / 6 \\
11 / 11 \\
10 / 10 \\
7 / 8 \\
8 / 9 \\
8 / 9\end{array}$ & $\begin{array}{r}5 \\
11 \\
6 \\
2 \\
3 \\
8\end{array}$ & $\begin{array}{l}4 \\
9 \\
1 \\
1 \\
5 \\
6\end{array}$ & $\begin{array}{r}7 \\
8 \\
9 \\
10 \\
11 \\
12\end{array}$ & $\begin{array}{c}10 / 11 \\
6 / 6 \\
7 / 11 \\
5 / 6 \\
8 / 10 \\
10 / 10\end{array}$ & $\begin{array}{r}7 \\
1 \\
1 \\
5 \\
2 \\
10\end{array}$ & $\begin{array}{l}7 \\
0 \\
0 \\
2 \\
8 \\
1\end{array}$ \\
\hline Totals & $50 / 53 \ddagger$ & 35 & 26 & $\ldots$ & $46 / 54 \S$ & 26 & 18 \\
\hline
\end{tabular}

* Number surviving out of number challenged.

$\dagger$ The enteropathogenic strain constituted $>30$ per cent. of the aerobic bacterial growth cultured from rectal swabs.

Three piglets died within $24 \mathrm{hr}$.

$\S$ Eight piglets died within $24 \mathrm{hr}$.

samples. Nine of 118 samples produced aerobic bacterial growth in which the enteropathogenic strain made up 30-80 per cent. of the flora. In 12 of 20 piglets that died from E.N.D., the infecting strain constituted more than 80 per cent. of the aerobic bacterial flora that was cultured from the anterior duodenum within $12 \mathrm{in} .(\mathrm{c} .30 \mathrm{~cm})$ of the pyloric sphincter. Thus, the pattern of infection in these piglets was that an almost pure culture of the enteropathogenic strain was recovered after aerobic culture from most of the samples taken from the small intestine of dead piglets.

\section{Infection experiments with litters from vaccinated dams}

\section{Mortality of piglets}

The mortality of piglets attributed to E.N.D. in litters from vaccinated dams is shown in table I. The maximum mortality was four of 11 infected in litters 7 
and 9 ; in two litters ( 8 and 12 ), no deaths occurred. The total mortality associated with E.N.D. was 20 per cent. (11 of 54 piglets) and the deaths of four piglets were not attributed to E.N.D. The mortality of the piglets from E.N.D. was analysed by means of a $\chi^{2}$ table separating the variation into two parts; variation between piglets from vaccinated versus non-vaccinated dams $\left(\chi_{1}^{2}=3.92\right)$, and variation between litters within the two groups $\left(\chi_{10}^{2}=16 \cdot 15\right)$. Although the $\chi_{10}^{2}$ value is not significant (95 per cent. significant value of $\chi_{10}^{2}=18.31$ ) it does suggest that there are differences in susceptibility between litters within both groups. Thus, the appropriate statistic for testing the reduction in mortality is the $t$ value $\left(t_{10}=\sqrt{\mathrm{F}_{1,10}}=1 \cdot 56\right)$ which is not significant (95 per cent. significant value of $t=1.81$ for a one-tailed $t$ test). Statistical analysis of the above figures therefore indicates that although there was an over-all reduction in mortality in piglets from the vaccinated dams, the reduction was not significant when the variability between litters was taken into account.

\section{Onset of diarrhoea and excretion of the enteropathogenic strain}

Twenty-six of 46 surviving piglets from vaccinated dams had diarrhoea within $24 \mathrm{hr}$ of infection (see table II) and rectal swabs cultured from 18 of 46 piglets showed that the enteropathogenic strain represented more than 30 per cent. of the aerobic flora. Thus, fewer piglets had diarrhoea and allowed the enteropathogenic strain to proliferate in the alimentary tract compared with the piglets from non-vaccinated dams. Rectal swabs cultured from only one of 16 piglets in litters 8 and 12 in which no deaths occurred contained the infecting strain at more than 30 per cent., although ten piglets in litter 12 had diarrhoea. On the other hand, eight piglets in litter 11 were excreting the enteropathogenic strain at more than the 30 per cent. level, but only two piglets had diarrhoea. The surviving piglets in litters 8 and 9 did not excrete a detectable amount of the enteropathogenic strain.

\section{Distribution of the enteropathogenic strain at necropsy}

The enteropathogenic strain was recovered as more than 80 per cent. of the aerobic bacterial flora from 14 of 67 samples taken from the small intestine of piglets that died from E.N.D. (see table III). On the other hand, 24 of 67 samples contained the enteropathogenic strain at the 30-80 per cent. level. The strain constituted more than 80 per cent. of the aerobic bacterial flora sampled from the anterior duodenum in only two of 11 piglets. Thus, in the piglets from vaccinated dams there was a reduction in the amount of the enteropathogenic strain in the alimentary tract, and fewer piglets had a pure culture of the organism in the anterior duodenum.

\section{Factors that may influence the development of E.N.D.}

Viable counts of the bacterial suspensions

The viable counts of the bacterial suspensions that each litter received showed minor variations (see table I). Litters $2,3,4,5$ and 6 received suspensions in 
which the range of viable counts differed by seven-fold. Although the two comparatively resistant litters (3 and 4) received suspensions with lower viable counts, it seems unlikely that small differences in the inoculum are sufficient to account for the considerable differences in susceptibility. In general, the viable counts of the bacterial suspensions administered to piglets from vaccinated dams were slightly less than the suspensions administered to piglets from nonvaccinated dams. Litter 8 , in which no deaths occurred, received the lowest

TABle III

Distribution of the $0149: K 91(B), K 88 a c(L)$ strain of Escherichia coli in samples taken at post mortem from the small intestine of piglets that died with experimental neonatal diarrhoea

\begin{tabular}{|c|c|c|c|c|c|c|c|}
\hline \multirow{2}{*}{$\begin{array}{l}\text { Litter } \\
\text { number }\end{array}$} & \multirow{2}{*}{$\begin{array}{l}\text { Total } \\
\text { samples } \\
\text { taken }\end{array}$} & \multicolumn{2}{|c|}{$\begin{array}{l}\text { Progeny of non-vaccinated dams: } \\
\text { numbers of samples in which } \\
\text { the strain constituted }\end{array}$} & \multirow{2}{*}{$\begin{array}{c}\text { Litter } \\
\text { number }\end{array}$} & \multirow{2}{*}{$\begin{array}{l}\text { Total } \\
\text { samples } \\
\text { taken }\end{array}$} & \multicolumn{2}{|c|}{$\begin{array}{l}\text { Progeny of vaccinated dams: } \\
\text { numbers of samples in which } \\
\text { the strain constituted }\end{array}$} \\
\hline & & $\begin{array}{l}30-80 \text { per cent. } \\
\text { of the aerobic } \\
\text { bacterial flora }\end{array}$ & $\begin{array}{l}>80 \text { per cent. } \\
\text { of the aerobic } \\
\text { bacterial flora }\end{array}$ & & & $\begin{array}{l}30-80 \text { per cent. } \\
\text { of the aerobic } \\
\text { bacterial flora }\end{array}$ & $\begin{array}{l}>80 \text { per cent. } \\
\text { of the aerobic } \\
\text { bacterial flora }\end{array}$ \\
\hline $\begin{array}{l}1 \\
2 \\
3 \\
4 \\
5 \\
6\end{array}$ & $\begin{array}{r}7 \\
38 \\
5 \\
6 \\
27 \\
35\end{array}$ & $\begin{array}{l}1 \\
0 \\
2 \\
0 \\
6 \\
0\end{array}$ & $\begin{array}{r}6 \\
37 \\
0 \\
1 \\
10 \\
30\end{array}$ & $\begin{array}{r}7 \\
8 \\
9 \\
10 \\
11 \\
12\end{array}$ & $\begin{array}{c}23 \\
0^{*} \\
26 \\
6 \\
12 \\
0^{*}\end{array}$ & $\begin{array}{r}4 \\
\dddot{13} \\
1 \\
6 \\
\ldots\end{array}$ & $\begin{array}{r}10 \\
\ldots \\
3 \\
1 \\
0 \\
\ldots\end{array}$ \\
\hline Totals & 118 & 9 & 84 & $\ldots$ & 67 & 24 & 14 \\
\hline
\end{tabular}

number of organisms; on the other hand, litter 12 , in which there were also no deaths, received the highest number of organisms in this group. These results support the conclusion that the differences in observed susceptibility are not attributable to small differences in the viable counts of the bacterial challenges.

\section{Antibody levels in serum and colostrum}

Non-vaccinated dams. The results of bacterial agglutination tests (table IV) show that bacterial agglutinins were present in the serum and colostrum of all of the gilts. The virtually negative results of tests with strains $\mathrm{J} 2$ and E68 type II as antigens suggest that the bacterial agglutinins were directed against the K88 antigen that was common to all the other strains (the $\mathrm{J} 2$ strain was motile and it possessed the K91 antigen). The titres of the bacterial agglutinins in the colostrum were generally greater than those of the serum samples, but the litters that were comparatively resistant to infection (nos. 3 and 4) received colostrum in which the agglutinin titre against the homologous group was four- to eightfold lower than the titres of the other samples of colostrum in the comparable series. 


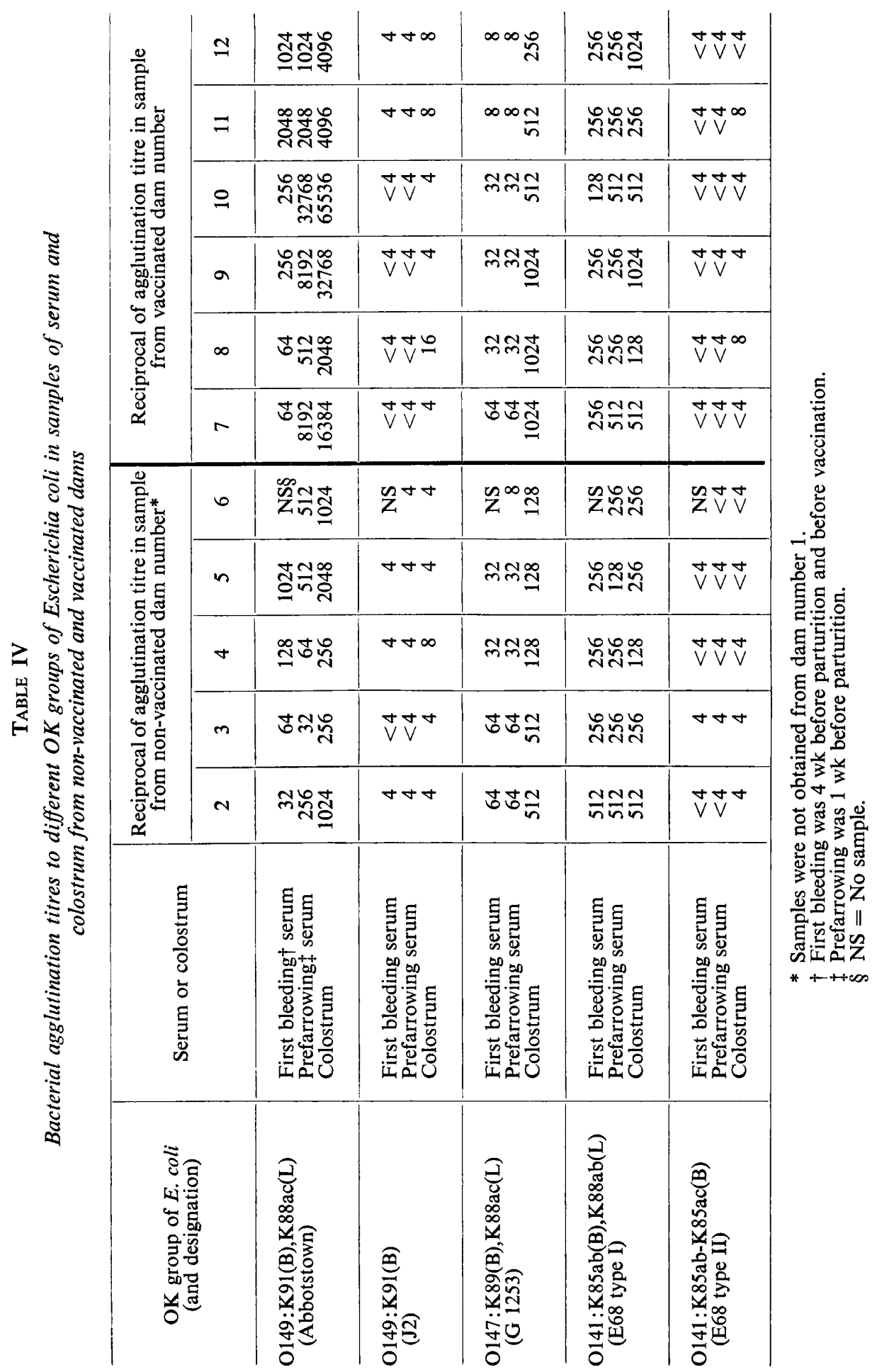




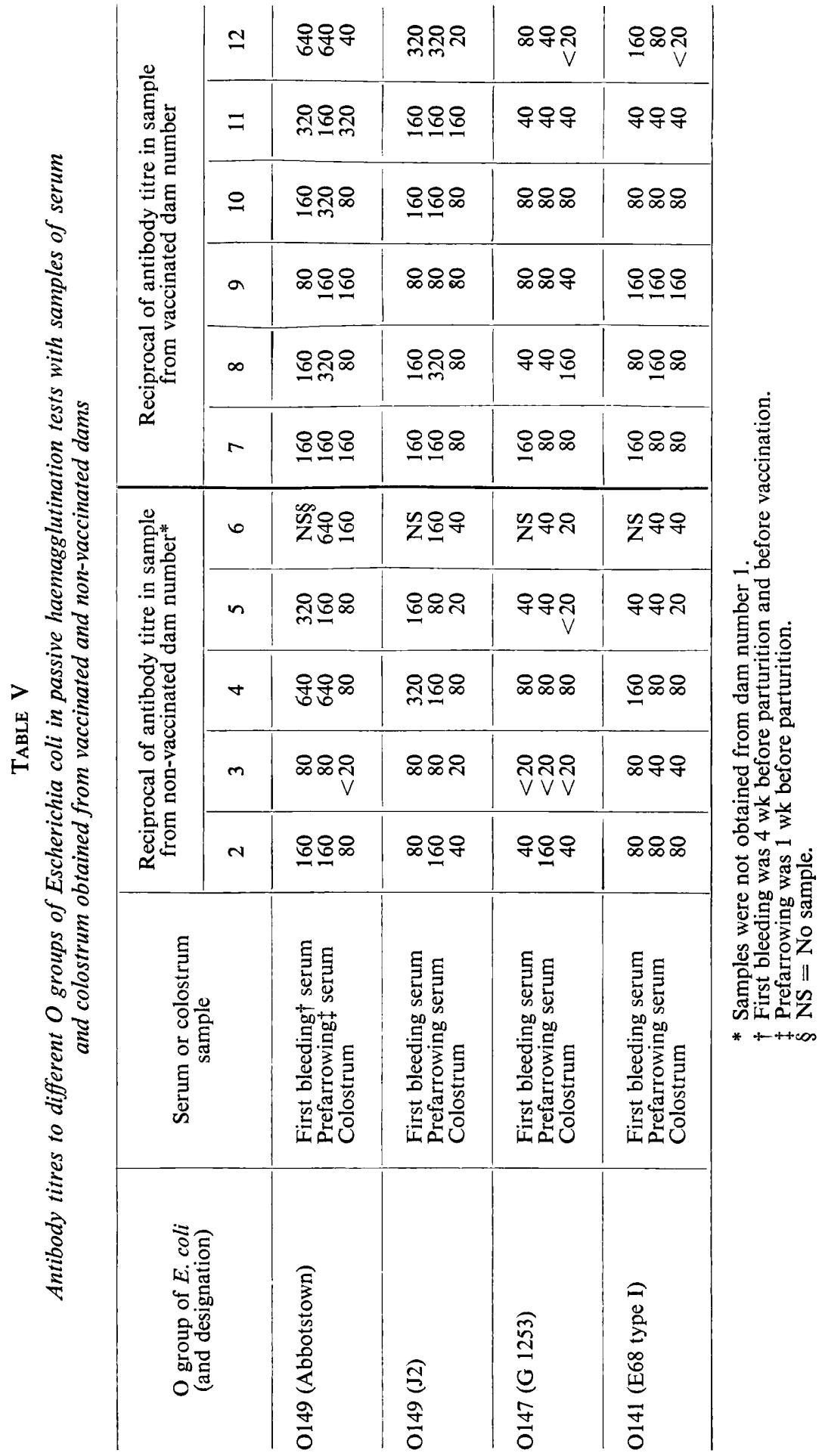


The results of passive haemagglutination tests (table V) show that the serum O-antibody titres varied from $<20$ to 640 . The antibody titres of the colostrum were less than those of the serum samples, and the findings with litters 3 and 4 showed clearly that there was no correlation between resistance and high antibody levels in the colostrum.

Vaccinated dams. All of the sera taken before vaccination contained demonstrable agglutinins to organisms with the K88 antigen (see table IV). The sera from four of the dams increased in titre as a result of vaccination, but when the

TABLE VI

The bactericidal effect of colostrum from non-vaccinated and vaccinated dams on the O149: $K 91(B), K 88 a c(L)$ strain of Escherichia coli in relation to the mortality rates in their litters attributable to E.N.D.

\begin{tabular}{|c|c|c|c|c|c|c|}
\hline \multirow{3}{*}{$\begin{array}{l}\text { Litter } \\
\text { number }\end{array}$} & \multirow{3}{*}{$\begin{array}{l}\text { Non-vaccinated }(C) \\
\text { or vaccinated }(V)\end{array}$} & \multirow{3}{*}{$\begin{array}{l}\text { Mortality of piglets } \\
\text { with experimental } \\
\text { neonatal diarrhoea }\end{array}$} & \multicolumn{4}{|c|}{$\begin{array}{l}\text { Percentage killing of the test strain } \\
\text { after } 1 \mathrm{hr} \text { incubation at } 37^{\circ} \mathrm{C} \text { with }\end{array}$} \\
\hline & & & \multicolumn{2}{|c|}{ colostrum } & \multicolumn{2}{|c|}{$\begin{array}{l}\text { colostrum plus } \\
\text { complement and } \\
\text { lysozyme }\end{array}$} \\
\hline & & & $\begin{array}{c}\text { mean of } \\
\text { duplicate tests }\end{array}$ & $\begin{array}{l}\text { group } \\
\text { mean }\end{array}$ & $\begin{array}{c}\text { mean of } \\
\text { duplicate tests }\end{array}$ & $\begin{array}{l}\text { group } \\
\text { mean }\end{array}$ \\
\hline $\begin{array}{l}3 \\
4 \\
5 \\
2 \\
6\end{array}$ & $\begin{array}{l}C \\
C \\
C \\
C \\
C\end{array}$ & $\begin{array}{l}1 \text { of } 10 \\
1 \text { of } 8 \\
4 \text { of } 9 \\
6 \text { of } 11 \\
5 \text { of } 9\end{array}$ & $\begin{array}{c}21 \\
15 \\
6 \\
0^{*} \\
12\end{array}$ & 11 & $\begin{array}{r}42 \\
23 \\
22 \\
33 \\
7\end{array}$ & 25 \\
\hline $\begin{array}{r}12 \\
8 \\
10 \\
11 \\
7 \\
9\end{array}$ & $\begin{array}{l}\mathrm{V} \\
\mathrm{V} \\
\mathrm{V} \\
\mathrm{V} \\
\mathrm{V} \\
\mathrm{V}\end{array}$ & $\begin{array}{l}0 \text { of } 10 \\
0 \text { of } 6 \\
1 \text { of } 6 \\
2 \text { of } 10 \\
4 \text { of } 11 \\
4 \text { of } 11\end{array}$ & $\begin{array}{r}16 \\
12 \\
9 \\
14 \\
16 \\
11\end{array}$ & 13 & $\begin{array}{l}31 \\
27 \\
37 \\
29 \\
40 \\
31\end{array}$ & 33 \\
\hline
\end{tabular}

$* 0=$ Growth in the test.

initial agglutinin titre was high (dams 11 and 12) the response to vaccination was minimal. In every case the samples of colostrum had higher titres than the serum samples, and the agglutinins for the O149:K91(B),K88ac(L) group were almost completely removed from the colostrum by prior incubation for $2 \mathrm{hr}$ at $37^{\circ} \mathrm{C}$ with the homologous strain. However, the two litters in which no deaths occurred ( 8 and 12) received colostrum that contained lower levels of homologous agglutinins than the other samples.

The results of passive haemagglutination tests (table $\mathrm{V}$ ) indicate that the $\mathrm{O}-$ antibody levels in serum and colostrum varied from $<20$ to 640 . There was no marked increase in the serum titres after vaccination and in general the samples of colostrum had titres lower than or similar to those of the serum samples. 


\section{Bactericidal activity of colostrum}

In tests without complement and lysozyme, the bactericidal activity of the colostrum from four of the five unvaccinated gilts (nos. 3, 4, 5 and 2) corresponded with the observed susceptibility of the piglets to E.N.D. (see table VI). However, the colostrum received by the susceptible litter no. 6 was almost as bactericidal as the colostrum received by the resistant litter no. 4 . When tests were done in the presence of complement and lysozyme there was no correlation between high levels of bactericidal activity in the colostrum and resistance of piglets to E.N.D. Similarly, there was no correlation between the resistance of piglets and a high level of bactericidal activity in the colostrum samples from vaccinated dams when tested in the presence or absence of complement and lysozyme. In both groups, the mean bactericidal activity of the colostrum increased in the presence of complement and lysozyme, but did not show a marked increase as a result of vaccination.

\section{Discussion}

The results of the present study confirm that the oral administration of a washed live suspension of an enteropathogenic strain of Escherichia coli to piglets at birth results in a disease syndrome that closely resembles natural outbreaks of neonatal diarrhoea (Saunders et al., 1963). The mortality that we observed with experimental neonatal diarrhoea (E.N.D.) was less than that reported by Saunders et al. and this may be attributable to differences in the virulence of the test strains of $E$. coli and in the susceptibility of the test piglets. In typical cases of E.N.D. in our series, diarrhoea began within $24 \mathrm{hr}$ of infection; the diarrhoea became progressively more fluid and the piglets rapidly became dehydrated so that most of the deaths occurred within $48 \mathrm{hr}$. An almost pure culture of the enteropathogenic strain was recovered when rectal swabs taken from these piglets were cultured aerobically.

Although a few piglets had diarrhoea continuously for up to 6 days, diarrhoea and excretion of the enteropathogenic strain by the surviving piglets generally ceased 1-2 days after infection. A recrudescence occasionally occurred at about day 4 and an almost pure culture of the infecting strain was subcultured from rectal swabs taken from these animals. In some cases there was moderately severe diarrhoea after challenge, but we recovered very few organisms of the enteropathogenic strain from rectal swabs; this diarrhoea was not related to the presence of extraneous enteropathogenic strains of $E$. coli in the alimentary tract.

The recovery of almost pure cultures of the infecting strain from the anterior duodenum of the majority (12 of 20) of dead piglets is in agreement with previous observations (Smith and Jones, 1963). However, pure cultures of the enteropathogenic strain were present only in the posterior small intestine of six of the remaining eight piglets that died. It is not clear from our observations whether the enteropathogenic strain was initially established in the anterior duodenum of these piglets after challenge, and a study of the events that occur within a few hours of infection is necessary to elucidate the early pathogenesis of the disease. 
Our results indicate that susceptibility to E.N.D. is primarily associated with the ability of the piglet to allow the enteropathogenic strain to establish and proliferate in the small intestine. In the resistant litters nos. 3 and 4, the diarrhoea was of shorter duration, fewer piglets excreted the infecting strain, there was a lower mortality and fewer samples cultured from the small intestine contained the enteropathogenic strain as the predominant aerobic organism. If establishment occurs, the final outcome of infection may be determined by the susceptibility of the piglet to the toxic products of bacterial proliferation. The resistance of litters does not appear to be attributable to high levels of " natural" antibodies in the colostrum although some of the samples had $\mathrm{O}$ antibodies and bacterial agglutinins presumably produced by previous exposure to the same or related antigens: the levels of bacterial agglutinins and passive haemagglutinating antibodies in the colostrum of dams 3 and 4 were lower than the corresponding figures for susceptible litters. Furthermore, it seems unlikely that differences in the bactericidal activity of colostrum are sufficient to account for the considerable variation in susceptibility. Resistance to E.N.D. may be an inherited factor and it is possible that some dams consistently produce resistant litters. The question also arises whether resistant female progeny themselves produce resistant litters.

Vaccination of the dams before parturition reduced the mortality of piglets challenged with E.N.D. from 38 per cent. to 20 per cent. No deaths occurred in two of the challenged litters from vaccinated dams, whereas two other litters had mortality rates of 36 per cent. When this variation in susceptibility is taken into account, the reduction in mortality of the piglets from vaccinated dams is not statistically significant $(P>0 \cdot 05)$. However, in addition to the reduction in mortality, the following differences were observed in the development of E.N.D. in piglets from vaccinated compared with non-vaccinated dams: in litters from vaccinated dams (i) fewer piglets had diarrhoea and the diarrhoea was of shorter duration; (ii) on the basis of results obtained with cultures from rectal swabs, the enteropathogenic strain proliferated in the intestine of fewer piglets; and (iii) 21 per cent. (14 of 67) of the samples from the small intestine of dead piglets contained the enteropathogenic strain as the predominant aerobic organism, whereas the corresponding figure for piglets from nonvaccinated dams was 71 per cent. (84 of 118). Assuming that a similar variation in susceptibility occurred in all of the litters, the bacteriological observations suggest that a superimposed antibacterial factor is modifying the course of the syndrome in piglets from vaccinated dams. Previous experiments have indicated that colostrum might be expected to have this effect (Porter, Noakes and Allen, 1970). In the present study, the results of bacterial agglutination tests showed that vaccination produced an increase in titre of agglutinins in almost all of the dams and that concentration of agglutinins occurred in the colostrum. However, the greatest protection (litters from dams 8 and 12) was associated with the lowest levels of agglutinins in the colostrum. The titres of passive haemagglutinating antibodies did not rise after vaccination; there was no concentration of this antibody in the colostrum and there was no correlation between antibody levels and resistance. The bactericidal action of colostrum did not correspond 
closely with the mortality rate in litters that had received it. Thus, although it was not possible to relate the protection of piglets to antibodies in the colostrum it seems likely that some component of the colostrum from vaccinated dams impaired the ability of the enteropathogenic strain to become established in the alimentary tract of their progeny. This factor has yet to be identified in vitro.

\section{SUMMARY}

Experimental neonatal diarrhoea (E.N.D.) was produced in litters of piglets derived from gilts after oral administration at birth of a washed live suspension of an enteropathogenic strain of Escherichia coli belonging to the O149:K91(B), $\mathrm{K} 88 \mathrm{ac}(\mathrm{L})$ group. Different litters varied in their susceptibility to the strain; the mortality attributable to E.N.D. was 38 per cent. ( 20 of 53 piglets) but two of six litters were almost completely resistant to the enteropathogenic strain. This resistance did not appear to be related to a high level of bacterial agglutinins, somatic (O) antibodies or bactericidal activity in the colostrum.

A formalin-killed vaccine derived from two isolates of the O149:K91(B), $\mathrm{K} 88 \mathrm{ac}(\mathrm{L})$ group was administered in two doses without an adjuvant to six gilts during the last $4 \mathrm{wk}$ of pregnancy. The mortality attributable to E.N.D. in piglets from vaccinated dams was 20 per cent. ( 11 of 54 piglets) following administration of the challenge dose. Although there was a reduction in the mortality of piglets from vaccinated compared with non-vaccinated dams, the reduction was not significant when the variation between litters was taken into account. However, the bacteriological observations suggest that an antibacterial factor impaired the ability of the enteropathogenic strain to become established in the intestinal tract of piglets from vaccinated dams. This factor did not appear to be related to a high level of bacterial agglutinins, somatic (O) antibodies or bactericidal activity in colostrum and has yet to be identified in vitro.

We are indebted to Mr G. W. Jones for providing the J2 strain, to Mr G. J. Rowlands for statistical analysis of the results and to Mrs C. Jay and Mr G. T. H. Brown for technical assistance. We are grateful to Mr W. J. Sojka, Central Veterinary Laboratory, Weybridge, for providing strains of Escherichia coli and to Mr J. R. Hepple, International Serum Laboratories, Hoechst U.K. Ltd, Mill Hill, London, for preparing the vaccine.

\section{REFERENCES}

Adinolfi, M., Glynn, A. A., Lindsay, Margaret, and Milne, Celia M. 1966. Serological properties of $\gamma \mathrm{A}$ antibodies to Escherichia coli present in human colostrum. Immunology, $10,517$.

CruicKSHANK, R. 1968. Medical microbiology, 11th ed. rev. reprint, Edinburgh and London, p. 744.

GorDON, W. A. M., AND LUKE, D. 1958. Gastro-enteritis in young piglets associated with Escherichia coli. Vet. Rec., 70, 542.

Gyles, C. L., AND BARnum, D. A. 1969. A heat-labile enterotoxin from strains of Escherichia coli enteropathogenic for pigs. J. Infect. Dis., 120, 419.

Jones, J. E. T., Sellers, K. C., ANd Smith, H. W. 1962. The evaluation of live and dead Escherichia coli vaccines administered to the pregnant female in the prevention of scouring (diarrhoea) in piglets. Vet. Rec., 74, 202. 
ØrSkov, IDA, Ørskov, F., WitTIG, W., AND SweEney, E. J. 1969. A new E. coli serotype O149:K91(B),K88ac(L):H10 isolated from diseased swine. Acta path. microbiol. scand., $75,491$.

Porter, P., Noakes, D. E., AND Allen, W. D. 1970. Secretory IgA and antibodies to Escherichia coli in porcine colostrum and milk and their significance in the alimentary tract of the young pig. Immunology, 18, 245.

Saunders, C. N., Stevens, A. J., Spence, J. B., ANd Sojka, W. 1963. Escherichia coli infection: reproduction of the disease in naturally-reared piglets. Res. Vet. Sci., 4, 333.

SMITH, H. W., AND JoNEs, J. E. T. 1963 . Observations on the alimentary tract and its bacterial flora in healthy and diseased pigs. J. Path. Bact., 86, 387.

Smith, H. W., ANd Halls, SheIla 1967. Studies on Escherichia coli enterotoxin. J. Path. Bact., 93, 531.

SoJKA, W. J. 1965. Escherichia coli in domestic animals and poultry, Farnham Royal. 